\title{
Utility of nintedanib for severe idiopathic pulmonary fibrosis: a single-center retrospective study [Corrigendum]
}

Abe M, Tsushima K, Sakayori M, et al. Drug Des Devel Ther. 2018;12:3369-3375.

On page 3372, last paragraph of "Results" section should read from "In Severe Group, patients who were able to continue nintedanib for more than 3 months $(n=4)$ exhibited significantly better prognosis compared to those who could not $(n=13)(P=0.007)$ (Figure 6)." to "In Severe Group, patients who were able to continue nintedanib for more than 3 months $(n=13)$ exhibited significantly better prognosis compared to those who could not $(\mathrm{n}=4)(P=0.007)$ (Figure 6)."

\section{Publish your work in this journal}

Drug Design, Development and Therapy is an international, peerreviewed open-access journal that spans the spectrum of drug design and development through to clinical applications. Clinical outcomes, patient safety, and programs for the development and effective, safe, and sustained use of medicines are the features of the journal, which

\section{Dovepress}

has also been accepted for indexing on PubMed Central. The manuscript management system is completely online and includes a very quick and fair peer-review system, which is all easy to use. Visit http://www.dovepress.com/testimonials.php to read real quotes from published authors. 